\title{
THE ROLE OF THE PPKn TEACHER IN IMPROVING STUDENT DISCIPLINE AT MUHAMMADYAH PRIVATE SD 2 BINJAI TIMUR
}

\author{
Arsip Perangin-Angin ${ }^{1}$, Ismail ${ }^{2}$, Seget Tartiyoso ${ }^{3}$, Sri Kurnia Hastuti Sebayang ${ }^{4}$, Dewi Rulia Sitepu \\ 1,2, PPKn Study Program, STKIP Budidaya Binjai, Indonesia \\ ${ }^{3}$ Mathematics Education Study Program, STKIP Budidaya Binjai, Indonesia \\ ${ }^{4}$ PBSI Study Program STKIP Budidaya Binjai, Indonesia \\ ${ }^{5}$ Mathematics Education Study Program, STKIP Budidaya Binjai, Indonesia E-mail: manurungisma@gmail.com, \\ arsippinem@gmail.com, sigittartiyoso25@gmail.com, hastutisrikurnia@gmail.com, dewiruliasitepu@gmail.com
}

ABSTRACT
The role of the PKN teacher is that with the motivation and directions given by the
Civics teacher, student discipline can be formed from the example of the teacher and also
from each one so that students are more disciplined in class and at school. Discipline is a
form of obedient behavior and is subject to applicable regulations, but compliance is more
emphasized on self-awareness not because of coercion. The school discipline applied to the
students of Muhammadiyah 2 Binjai Timur Private. Elementary School is quite good
so that the discipline applied at school becomes positive. This research was conducted by
means of observation and interviews with the principal of SD Swasta Muhammadyah 2 Binjai
Timur with homeroom teachers and several students.

\section{INTRODUCTION}

Discipline is a form of obedient behavior and is subject to applicable regulations, but compliance is more emphasized on self-awareness not because of coercion (Milgram, 1963) (Anderson \& Putterman, 2006). However, in reality, many human disciplinary behaviors are motivated by coercion or restrictive rules (Foucault, 2007). So the assumption that develops among the community that discipline means rigid and scary.

Education is a part of life. Through education, human intelligence and skills are more honed and tested in the face of increasingly complex dynamics of life (Teece, Pisano, \& Shuen, 1997). Law No. 22 of 2003 states that schools are trying to implement school rules in an effort to shape the character and civilization of a dignified nation and print the next generations of the nation in accordance with the Indonesian human personality based on Pancasila through education, especially Citizenship Education.

Discipline is one of the most important life skills and needs to be possessed by everyone in order to achieve success in life (Bridgstock, 2009; Cimatti, 2016; Senge, Cambron-McCabe, Lucas, Smith, \& Dutton, 2012), not only success in learning but also success in social life. Discipline in the order in life when specifically detailed and broken down from aspect by aspect will produce ethics as norms that apply in association, including also in relations with the surrounding environment.

The purpose of this study was to determine the efforts of teachers to improve discipline through Civics lessons and to find out the factors that became obstacles in the efforts of Civics teachers in improving student discipline.

\section{RESEARCH METHOD}

This type of research is a qualitative research using analysis. The location of this research will be carried out at the Muhammadiyah Private Elementary School 2 Binjai Timur. This research was conducted in the odd semester of the 2017/2018 academic year. In this study, the subjects were students of SD Swasta Muhammadyah 2 Binjai Timur, while the object of this research was the improvement of discipline.

The process of data analysis in this study was carried out continuously from the beginning to the end of the study, both in the field and outside the field (Bungin, 2003). Data analysis takes place simultaneously with the data collection process (Sugiyono, 2019). Among them are data reduction, data presentation and conclusion/verification.

\section{A. General Findings}

\section{RESULTS AND DISCUSSION}

1. The history of the establishment of the Muhammadiyah Private Elementary School 2 Muhammadyah 2 Private Elementary School is a school located in the city of Madiah Binjai which is located at Jalan Danau Tempe, Kec. East Binjai City of Binjai. Muhammadyah 2 Private Elementary School is in great demand because of its strategic location and also the school's condition is quite comfortable and school discipline is quite strict.

\section{How to cite:

Arsip Perangin-Angin, Ismail, Seget Tartiyoso, Sri Kurnia Hastuti Sebayang, Dewi Rulia Sitepu. (2021). The Role of The Ppkn Teacher in Improving Student Discipline at Muhammadyah Private SD 2 Binjai Timur. Journal of Eduvest. Vol 1(11): Page 1385-1388 2775-3727

https://greenpublisher.id/ 
2. Vision and Mission of Muhammadiyah 2 Binjai Timur Private Elementary School

a. Vision of Muhammadiyah 2 Binjai Timur Private Elementary School Creating a generation that is faithful and devoted and able to carry out the mandate of Muhammad

b. Mission of Muhammadiyah 2 Binjai Timur Private Elementary School Increase the commitment and excellence of graduates who are skilled in national/international standard competence through:

1) Carry out effective learning supervision and guidance so that each student develops optimally according to their potential

2) To foster a spirit of competence for all school members to achieve achievements in the fields of science and skills according to the program they have.

3) Organizing educational programs rooted in the religious value system, customs and culture of the community while keeping abreast of developments and the era of globalization

4) Creating a safe, orderly, clean, cool and beautiful school environment and fostering a sense of kinship.

3. The purpose of the Muhammadiyah 2 Binjai Timur Private Elementary School

1) Improving the thinking power and creativity of citizens according to their potential

2) Improving achievements and fields of knowledge and skills of school residents, as well as maintaining and preserving the values of the nation's cultural character

3) Improving human resources in the quality of education while keeping abreast of the developments of the globalization era

4) Increase a sense of security, order, cool and beautiful to realize the creativity of school community performance

5) Achievement of PAIKEM learning with Joy Learning nuances

6) Achieving the balance of IMTAQ and science and technology

7) The achievement of the school environment as a source of student learning

8) Achievement of proud school outputs for the community and schools.

4. Facilities and Infrastructure

Table 1 Facilities for Muhammadiyah 2 Binjai Timur Private Elementary School

\begin{tabular}{llll}
\hline No & Type of facility & Total & Condition \\
\hline 1 & Principal's Room & 1 & Good \\
\hline 2 & Teacher's room & 1 & Good \\
\hline 3 & Administration room & 1 & Good \\
\hline 4 & Study room & 6 & Good \\
\hline 5 & UKS room & 1 & Good \\
\hline 6 & library & 1 & Good \\
\hline 7 & Bathroom & 3 & Good \\
\hline 8 & Parking & 2 & Good \\
\hline
\end{tabular}

5. School Physical Condition

a. School Physical Condition

1) Land area : $4,800 \mathrm{~m} 2$

2) Number of classrooms: 6 rooms

3) Classroom size : $9 \times 6 \mathrm{~m} 2$

b. The State of the School Environment

1) Types of buildings surrounding the school: Mosque, Residential area

2) School environmental conditions: Well, Comfortable

c. School Facilities

1) Library : OK

2) Administration room: OK

d. Teachers and Students

1) Number of Teachers: 6 People

2) Number of students per class: 35 students

3) Total number of students: 420 students

6. The State of the Educators of the Muhammadiyah 2 Binjai Timur Private Elementary School The teaching staff at SD Swasta Muhammadyah 2 Binjai Timur are generally educators whose level of educational qualification is academically experienced Bachelor (S1). The educators for the Muhammadiyah 2 Binjai Timur Private Elementary School are as follows:

Table 2 Number of teaching staff at the Muhammadiyah 2 Binjai Timur Private Elementary

\begin{tabular}{llll}
\multicolumn{3}{c}{ School } & \\
\hline No & Gducator & Position & \\
\cline { 2 - 3 } & $\mathrm{M}$ & $\mathrm{F}$ \\
\hline
\end{tabular}


Eduvest - Journal of Universal Studies

Volume 1, Number 11, February, 2022

\begin{tabular}{lllll}
\hline 1 & 1 & 1 & - & Head Master \\
\hline 2 & 1 & 1 & - & School Security Patrol \\
\hline 3 & 15 & 5 & 10 & Teacher \\
\hline Total & 17 & 7 & 10 & \\
\hline
\end{tabular}

The table above shows that there are 15 teaching staff (teachers).

Table 3. Number of Staff of Muhammadiyah 2 Binjai Timur Private Elementary School No Employee Gender

\begin{tabular}{|c|c|c|c|c|c|}
\hline & Position & $\mathrm{M}$ & $\mathrm{F}$ & & \\
\hline 1 & 1 & 1 & - & $\begin{array}{l}\text { Head } \\
\text { Administration }\end{array}$ & of \\
\hline 2 & 1 & - & 1 & Administrative & staff \\
\hline Total & 2 & 1 & 1 & & \\
\hline
\end{tabular}

The table above shows that the number of employees at SD Swasta Muhammadyah 2 Binjai Timur is 2 people, consisting of 1 administrative head and 1 administrative staff.

Table 4 Number of Civics Teachers at Muhammadiyah 2 Primary School in East Binjai

\begin{tabular}{llll}
\hline No $\quad$ Teacher's name & Parenting Class & Education & Number of \\
Foster Students & $1^{\text {a dan b }}$ & S-1 PPKn70 & \\
\hline 1 Sofia, S.Pd &
\end{tabular}

From the table above, it can be seen that the number of Civics subject teachers in Muhammadiyah 2 Binjai Timur Private Elementary School is 1 (one) it is known that Civics subject teachers are graduates (S-1) of Civics, so Civics subject teachers are in accordance with their fields or in accordance with with his profession at the Muhammadiyah Private Elementary School 2 Binjai Timur, he has a fairly reliable teaching staff where every subject teacher runs linearly according to his department, including Civics subject teachers who are considered capable enough to educate students to become disciplined, honest, moral, and ethical students. ethical and responsible.

Table 5. The total number of students of SD Private Muhammadyah 2 Binjai Timur

\begin{tabular}{|c|c|c|c|c|c|}
\hline No & Class & Student & & Local amount & Total students \\
\hline & & Male & Female & & \\
\hline 1 & I & 30 & 40 & 2 & 70 \\
\hline 2 & II & 30 & 40 & 2 & 70 \\
\hline 3 & III & 40 & 30 & 2 & 70 \\
\hline 4 & IV & 25 & 45 & 2 & 70 \\
\hline 5 & V & 25 & 45 & 2 & 70 \\
\hline 6 & VI & 35 & 35 & 2 & 70 \\
\hline Total & & 185 & 235 & 12 & 420 \\
\hline
\end{tabular}

\section{B. Special Findings}

1. Interview with the principal

2. Interview with the homeroom teacher

3. Interviews with several students

From all interviews conducted, it can be concluded that the role of PPKn teachers in improving discipline at SD Muhammadyah 2 Binjai Timur has been carried out by all teachers. With the motivation and directions from the teacher, student discipline can be formed from the example of the teacher.

Then from the results of observations and interviews at the Muhammadiyah 2 Binjai Timur Private Elementary School whose research has been carried out, it can be seen that the role of PKN teachers in improving student discipline in schools has a fairly important role where the main role is in the teacher workforce.

\section{Discussion of Research Results}

The results of interviews conducted with school principals, namely schools have developed regulations, punishments, rewards, and consistency. In reality, the principal has implemented regulations for the teacher and student councils through the application of punishment, rewards, and consistency. The application of discipline in schools can be seen from how all students obey school rules, be orderly, and disciplined to control their attitudes and behavior on a daily basis.

The results of observations made indicate that the socialization of the rules of conduct in schools is quite good with the existence of a pocket book containing the rules that apply in schools that must be obeyed 
by all students. In addition, efforts to socialize the rules of conduct at the Muhammadiyah 2 Binjai Timur Private Elementary School were also carried out through MOS activities.

Awards for students who are disciplined in time, orderly, obedient, and achievers are not seen during the researchers conducting research. However, based on the results of the interview, the principal revealed that students who are obedient and always disciplined in obeying the rules will be given praise as "there is an award for disciplined students, we give mass appreciation at the ceremony, and show respect for students".

This discipline is useful in teaching students to understand and behave well that every behavior will be followed by punishment and reward. In addition, helping students develop control, direction, and provide instruction in their conscience to guide their every action. If all students can think positively that being disciplined is important, it will have a good impact on them where every action they act will be balanced by self-control. The application of discipline in schools is seen from how students obey school rules, be orderly, and disciplined in order to control their attitudes and behavior on a daily basis.

The results of interviews and observations of the principal in giving awards to students in the form of words during the flag ceremony, to students who orderly participate in ceremonial activities. This is in accordance with the results of the interview that: "At the school flag ceremony activities always give awards in the form of advice, motivation, or congratulations for students who orderly participate in ceremonial activities or students who have good achievements".

The principal's efforts in giving awards to students are quite frequent where every time there is an activity the principal always gives rewards and motivation, although in practice awards in the form of objects are rarely given and more awards are given at school in the form of words of instruction than gifts of objects, because awards are in the form of words. words more quickly stimulate and motivate students.

Discipline has been applied by the Citizenship Education teacher at the Muhammadiyah 2 Binjai Timur Private Elementary School. Efforts to improve discipline are not only carried out in learning, but in every opportunity. Efforts to improve discipline through the learning process of Citizenship Education can be seen from the syllabus and lesson plans.

\section{CONCLUSION}

The results of this study conclude that discipline is a process for training and educating a person's behavior in accordance with the rules or regulations that apply either arising from his awareness or because of sanctions or punishments that apply with a full sense of responsibility and wholeheartedly, so that if he does something Violation will arise a feeling of guilt, shame, fear and do not want to do the act again. Student discipline is the attitude or behavior of students who are obedient and obedient to be able to carry out their obligations to study, both studying at school and studying at home.

Learning discipline and school atmosphere with student achievement at SD Swasta Muhammadyah 2 Binjai Timur, has a strong and significant positive relationship. Discipline in learning and a good school atmosphere will encourage students to study optimally so that the achievement obtained is even higher.

\section{REFERENCES}

Anderson, Christopher M., \& Putterman, Louis. (2006). Do non-strategic sanctions obey the law of demand? The demand for punishment in the voluntary contribution mechanism. Games and Economic Behavior, 54(1), 1-24.

Bridgstock, Ruth. (2009). The graduate attributes we've overlooked: Enhancing graduate employability through career management skills. Higher Education Research \& Development, 28(1), 31-44.

Bungin, Burhan. (2003). Analisis Data Penelitian Kualitatf Jakarta. Raja GrafindoPersada.

Cimatti, Barbara. (2016). Definition, development, assessment of soft skills and their role for the quality of organizations and enterprises. International Journal for Quality Research, 10(1).

Foucault, Michel. (2007). Discipline and punish: The birth of the prison. Duke UniversityPress.

Milgram, Stanley. (1963). Behavioral study of obedience. The Journal of Abnormal and Social Psychology, 67(4), 371.

Senge, Peter M., Cambron-McCabe, Nelda, Lucas, Timothy, Smith, Bryan, \& Dutton, Janis. (2012). Schools that learn (updated and revised): A fifth discipline fieldbookfor educators, parents, and everyone who cares about education. Currency.

Sugiyono, Prof. Dr. (2019). Metode Penelitian Kuantitatif Kualitatif dan R\&D. Bandung:Alfabeta.

Teece, David J., Pisano, Gary, \& Shuen, Amy. (1997). Dynamic capabilities and strategic management. Strategic Management Journal, 18(7), 509-533 